\title{
Decentralised, Sustainable Energy Solutions for Remote Areas
}

\author{
C.Facchin ${ }^{1}$, A.Waterworth ${ }^{1}$ and W.Weston ${ }^{1}$ \\ ${ }^{1}$ Department of Engineering and Technology \\ University of Huddersfield, Huddersfield HD13DH, UK \\ Phone: +44 7778 408572, email: a.waterworth@hud.ac.uk, w.weston@hud.ac.uk
}

\begin{abstract}
.
This report investigates the potential use and applicability of small scale, renewable energy sources (namely wind, hydro and solar power) in remote communities (specifically in India, Nepal, the USA and the South Atlantic). The report finds that hydro, wind and solar power can all be used to generate small scale off-grid energy. However, different locations require different methods of energy generation based on their climate and geography; for example the relatively flat and arid South Dakota (USA) is not suited for hydropower. Conversely, Uttar Pradesh (India) has low wind speeds and so wind power is not a viable option there. The report also notes the limitations of this study and makes recommendations for future investigation.
\end{abstract}

\section{Key words}

Remote energy solutions, hydroelectric power, wind power, solar power.

\section{Introduction}

\section{A. Background}

The standard model of energy distribution in the developed world is for a number of large power stations to generate the entire country's energy needs. This electricity is then distributed via power lines around the country based on demand [1]. This method works well in developed countries as a smaller number of large power stations can supply energy to densely populated urban areas.

There are some regions in the world however where this approach is simply not feasible [2]. This can be for a combination of reasons, such as geographic isolation, economic reasons or even due to the destruction of necessary infrastructure during warfare or natural disasters. In such cases, small settlements in remote areas can be left without any centralised electrical supply.

The only options available traditionally to remote communities is to get by without the aid of electricity, or to use diesel generators. However, it has been acknowledged that access to energy is a "key component" to reducing poverty [3], so the former option is becoming increasingly unfeasible in the modern world. The latter option can be impractical in remote communities plus the price of crude oil generally continues to rise as supply decreases [4].

As such, in many remote areas, it would be better for local, small scale (less than a few hundred kilowatts) sustainable energy generators to be put in place. The potential benefit of this approach is two-fold. Firstly, it will allow a greater degree of energy independence, as energy will be generated using local resources rather than imported fuel, and secondly the local people can be educated on the use of these generators, and can then be employed to maintain them. This not only increases local knowledge and technical skills, but it has been found that creating a greater sense of engagement with the local community increases the chances of the long term success of sustainable energy projects [3]. Non- technical factors, such as a sense of ownership and gender inclusiveness are key to the success of a project, that is, it must be clear whose job it is to maintain and run the generators, it is also essential for women to be included in its maintenance and use, otherwise the generators would fall into disuse.

\section{B. Brief review of some previous studies}

Programmes are driven by social as well as economic concerns as identified in the study in 2012 by the US Office of Energy Efficiency and Renewable Energy (EERE) which discussed small scale renewable energy solutions for Native American tribes necessitated by their extreme poverty levels. Their utility bills were disproportionately high ( $\$ 400 /$ month) despite lower life expectancy and an $85 \%$ unemployment rate. As such, the Tribal Lands program was founded with aims to reduce the cost of energy bills, improve living conditions, develop employment options and build renewable energy skills within the community. It determined that supplemental solar heaters returned their investment within 3 years, and should continue to save $\$ 400$ a year on energy bills for another 20 years. Local people were 
taught installation and maintenance skills, creating local jobs and improving the economy. Small scale wind turbines and photovoltaic systems were not cost effective $[5]$.

Sustainability challenges in Yogyakarta, Indonesia in 2012 led to the evaluation of micro-hydropower, solar power and biogas using a variety of substrates (cattle waste, tofu and human waste). The study found that local people, whilst requiring the proper technical training in order to be successful, were more willing to maintain and operate biogas generators rather than those than run on fossil fuels. Further, the study found that no matter the substrate, the biogas generates were capable of running at $71 \%$ to $96 \%$ of their rated output.

This study proves that there is a need for decentralised and sustainable energy solutions in many parts of the world. However, sites need to be properly evaluated in order for the cost effective solution to be found and proper maintenance and training needs put in place for these systems to work effectively [6].
Bauer et al compared biogas and bioethanol with regard to energy production and environmental impact. The report finds that biogas, obtained by fermenting a mix of corn silage and cow dung gave 3.8 times the yield per hectare compared with land given over to sugar cane and corn for bioethanol production, highlighting the importance of using land efficiently and wisely [7]. Other studies [8] also determined biogas to be the most effective method of generating renewable energy.

This study demonstrates an identifiable need for sustainable energy solutions for marginalised villages although in order to be successful, technical and nontechnical factors need to be taken into account [8]. The most successful projects maintained their usefulness by ensuring that local technicians were taught how to install and maintain the systems [3]. Not only does this ensure that there is a sense of ownership, it also means that outside help does not need to be called for and so any technical issues are dealt with swiftly.

\begin{tabular}{l|l|l|l|l|}
\cline { 2 - 4 } $\begin{array}{l}\text { Also } \\
\text { in } \\
2012,\end{array}$ & Device & Power (kW) & $\begin{array}{l}\text { Hours in Use per } \\
\text { day (h) }\end{array}$ & $\begin{array}{l}\text { Energy Usage } \\
\text { (kWh)/day/home }\end{array}$ \\
\cline { 2 - 5 } & Lightbulbs (x2) & $0.06 \times 2=0.12$ & 4 & 0.48 \\
\cline { 2 - 5 } Table & Refrigerator & 0.3 & 24 & 7.2 \\
\cline { 2 - 5 } & Air Heater & 2 & 3 & 6 \\
\cline { 2 - 5 } & Stove & 1 & 2 & 2 \\
\cline { 2 - 5 } & Total & $\mathbf{3 . 4 2}$ & $\mathbf{1 5 . 6 8}$ \\
\hline
\end{tabular}

Typical Energy Demands (Energy Use calculator, 2015)

\section{Analysis of some available technologies}

The typical energy demands of an 'average' home are given Table I above. Assuming a village comprises of 50 such homes then a total peak power demand of $171 \mathrm{~kW}$ and energy consumption of $784 \mathrm{kWh}$ per day is required. This information is used to determine the most appropriate technology for each of the chosen locations.

\section{A. Hydroelectricity Technology}

There are two broad categories of hydro turbines (which can then be further subdivided into specific designs); impulse turbines, which work on the principle of momentum being transferred from the water to the turbine; and reaction turbines, which work by water passing over the turbine blades creating a pressure differential which then produces lift and leads to the turbine rotating.

Different turbines have different operating conditions, (high head/low flow lends itself to impulse turbines, low head/high flow lends itself to reaction turbines) and so the site needs to be evaluated fully before choosing which type of turbine to implement. Examples of impulse turbines include Turgo turbines and Pelton wheels. Examples of reaction turbines include propeller turbines and Francis turbines [9]. The size of hydropower that is being investigated in this paper is termed mini hydro (up to $500 \mathrm{~kW}$ ), micro hydro (up to $100 \mathrm{~kW}$ ) or pico hydro (less than $5 \mathrm{~kW}$ ) [10]. The size of the community being serviced,

and the available resources, will determine whether mini, micro, or pico hydro systems are implemented.

The power available from a hydroelectric turbine is given by:

$$
P=\rho H Q g \eta
$$

where $\mathrm{P}$ is the power $(\mathrm{W})$,

$\mathrm{H}$ is the head (m),

$\mathrm{Q}$ is the flow rate $\left(\mathrm{m}^{3} / \mathrm{s}\right)$, 
$\mathrm{g}$ is the acceleration due to gravity $\left(9.81 \mathrm{~m} / \mathrm{s}^{2}\right)$,

$\rho$ is the density of water $\left(1000 \mathrm{~kg} / \mathrm{m}^{3}\right)$ and

$\eta$ is the efficiency of the turbine system (typically between $80 \%$ and $90 \%$. ( $85 \%$ is assumed for calculations in this report).

The head and flow rate both influence the power with a high flow rate compensating for a low head. For example, in a hypothetical stream with a flow rate of 1 $\mathrm{m}^{3} / \mathrm{s}$, the head required to supply the example village with $171 \mathrm{~kW}$ can be calculated as $20.51 \mathrm{~m}$ but if the flow rate was doubled to $2 \mathrm{~m}^{3} / \mathrm{s}$ then the required head would be halved to $10.25 \mathrm{~m}$. This shows how a relatively small stream can be utilised if there is a steep gradient (or a steep gradient can be created, using a dam), or a larger stream can still be useful if the area is relatively flat.

Fig. 1 gives some typical flow rate values for various sizes of stream, along with a minimum head needed in order for a feasible project. These values are used as a rough guideline in this paper because of the lack of suitable site data.

\section{B. Photovoltaic Technology}

PV cells work by converting solar energy into electricity when sunlight strikes the cell. This necessitates that the cells are placed in such a way that they receive maximum direct sunlight and are most useful in areas that receive a large amount of sunlight consistently throughout the year, such as desert areas. However, as they heat up they become less efficient, and even in ideal conditions only have approximately $15 \%$ efficiency. Another area of use for PV may be in tundra or mountainous regions during summer, where there is high sunlight but relatively low temperatures.

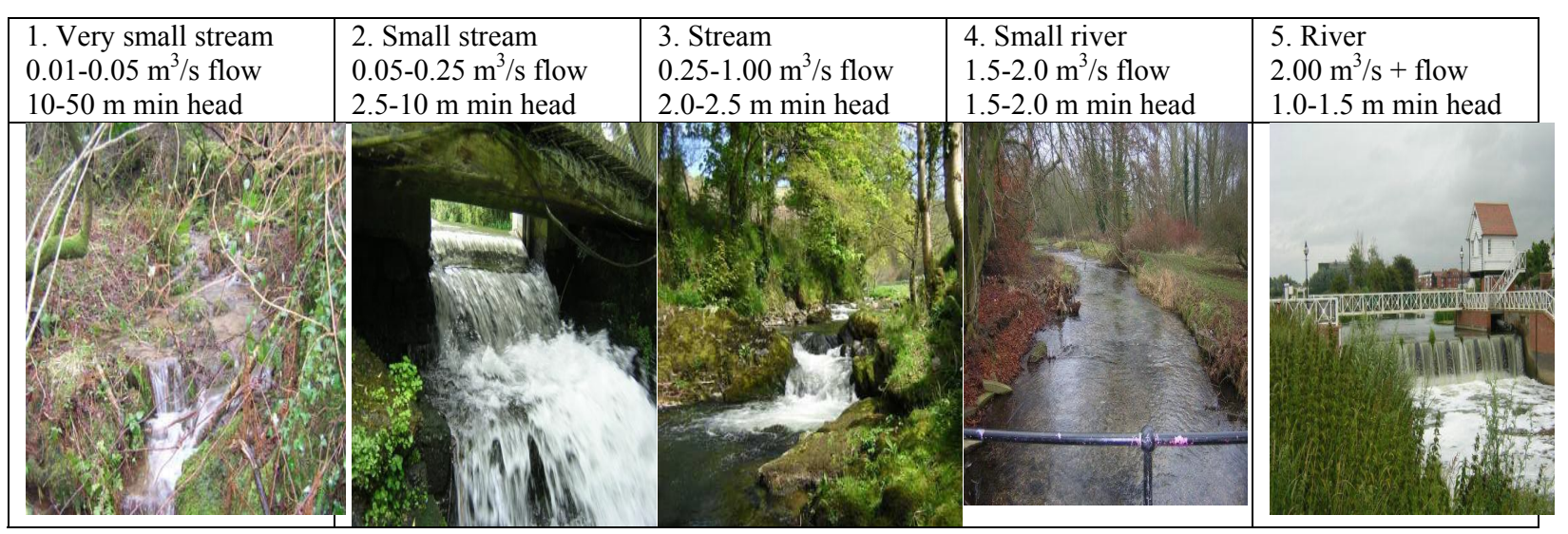

Fig. 1. Stream and river categories (Micro Hydro Power Company)

The energy available from solar panels is determined from:

$$
E=A \times r \times H \times P R
$$

where $\mathrm{E}=$ annual energy generated $(\mathrm{kWh})$,

$\mathrm{A}=$ total area of PV panels $\left(\mathrm{m}^{2}\right)$,

$\mathrm{r}=$ solar panel yield,

$\mathrm{H}=$ the annual solar irradiation $\left(\mathrm{kWh} / \mathrm{m}^{2}\right)$ and

$\mathrm{PR}=$ performance ratio of the installation.
The solar panel yield (r) is calculated by dividing the peak power output of a solar panel by the area of one panel and the performance ratio (PR) is dependent on a number of factors and inefficiencies, such as temperature and transmission losses, and losses due to shading of the panels etc. A default value of 0.75 is used here but normally this value would be specific for each site. The annual solar irradiation depends on the amount of sunlight available at a given site and can vary between $200 \mathrm{kWh} / \mathrm{m}^{2}$ in Norway up to $2600 \mathrm{kWh} / \mathrm{m}^{2}$ in Saudi Arabia. Fig. 2 shows how this value varies across the globe: 


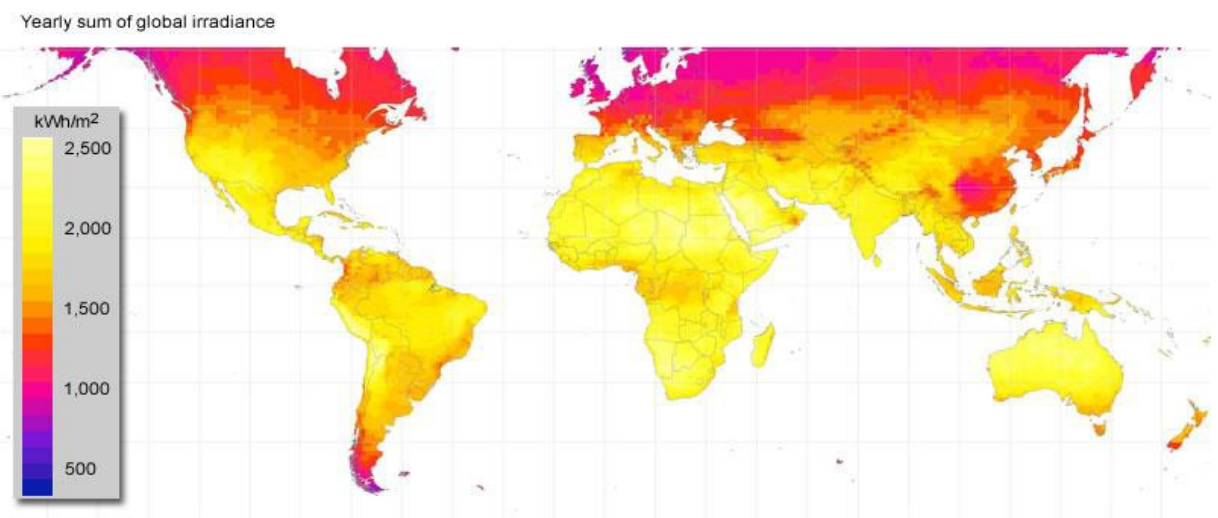

Fig. 2. Annual Solar Irradiation (Photo-Voltaic Software, 2014)

The energy demands of the notional 50 home village is calculated as $286 \mathrm{MWh} / \mathrm{yr}$, which can be used to compare the effectiveness of each chosen solution with equation (2) being rearranged to determine the solar panel area required to generate sufficient energy. The energy demand is considered constant for the hypothetical village regardless of its location. The yield and performance ratio are also considered constant as the same panel design will be used for any location and it is assumed all losses will be the same. The only variable is the annual solar irradiation, which is determined by geography.

\section{Wind Power}

The maximum efficiency for wind turbines is $59.3 \%$ due to conservation of mass and momentum of air passing over a turbine, regardless of whether using VAWTs or HAWTs. Ideally, wind turbines are best placed in areas away from obstructions, as a minimum average wind speed of $7 \mathrm{~m} / \mathrm{s}$ at a height of $25 \mathrm{~m}$ above the Earth's surface is needed to produce a feasible amount of electricity. This means ideal locations are offshore, tundra or high altitude areas.

Wind is not locally predictable in the short term so wind power should not be relied upon to generate $100 \%$ of an area's energy needs. They also have to be protected and shut down in high winds [9]. The power generated from wind can be calculated from:

$$
P=12 \rho A \mathrm{v}^{2} C P
$$

where $\rho=$ density of air $\left(1.23 \mathrm{~kg} / \mathrm{m}^{3}\right)$,

$\mathrm{A}=$ area swept by wind turbine $\left(\mathrm{m}^{2}\right)$,

$\mathrm{v}=$ wind velocity $(\mathrm{m} / \mathrm{s})$ and

$\mathrm{CP}=$ ratio between available wind power and generated power.

The CP is known to be less than 0.593 (the Betz limit) and is dependent on the tip-speed ratio and the turbine design (Fig. 3) yielding a maximum CP practical value of 0.4 . Horizontal axis wind turbines are considered more efficient than vertical axis although they have to face into the wind so a HAWT variant is used in this paper.

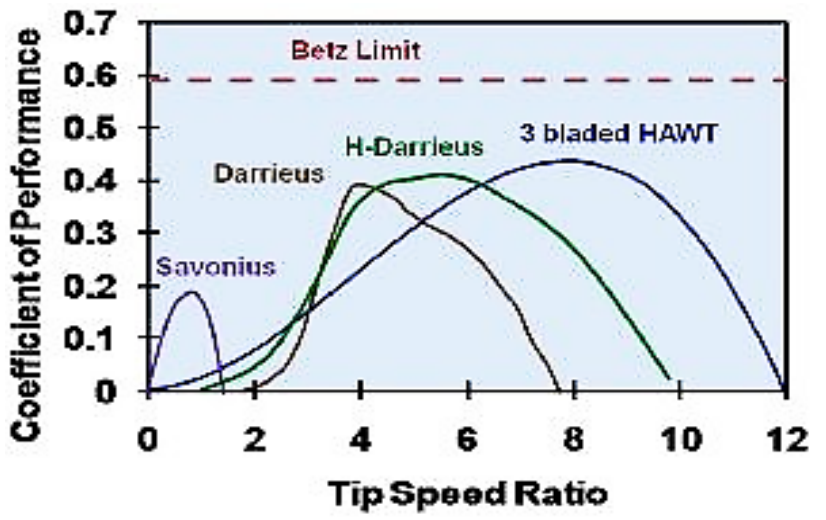

Fig. 3. Coefficient of performance v Tip speed ratio (Wind Turbine Performance, n.d.)

\section{Biofuels}

The three related biofuel technologies, biodiesel, bioethanol and biogas take either waste or specially grown natural products and combust them in a generator to produce heat and electricity.

Biodiesel refers to waste oils such as vegetable oil from cooking, sunflower, etc., whereas bioethanol uses fermented sugar cane in order to produce ethanol which is then used to enrich fuel mixtures or, used on its own.

Biogas is created by the anaerobic digestion of waste materials in order to produce methane.

Biofuels are undoubtedly an important source of renewable energy but their suitability depends on the local area's available arable land which is not used to grow food. Without reliable data it is difficult to project the suitability of biofuels for a settlement and so the use of biofuels is not be considered here.

\section{E. Geothermal}

The potential energy from geothermal sources is huge, however, it is limited in the number of suitable sites because, although technically it can be used anywhere, the cost of drilling deep enough for the Earth's temperature to be sufficient to produce sufficient energy 
can be prohibitive. It is only suitable in areas that have relatively high tectonic activity e.g. Iceland.

\section{Some locations and solutions}

\section{A. Uttar Pradesh, India}

Uttar Pradesh is a state in Northern India with approximately 10,000 villages without electricity [10] and a summary of local relevant climate and geographic conditions yields that the state has:

(i) heavy rainfall, unevenly distributed throughout the year with many rivers;

(ii) low wind speeds;

(iii) a flat and low lying topography;

(iv) long days, relatively high solar irradiation and;

(v) warm weather, it never freezes.

From this, initial solutions point towards a combination of hydropower and solar power. The low wind speeds suggest that wind power would not be viable. Firstly, solar power will be explored. In order to generate $100 \%$ of the required energy for the hypothetical village, the area of solar panels required needs to be calculated. Online data from the National Energy Laboratory gives hourly readings for the solar irradiation on a cell within Uttar Pradesh [11]. From this data the average solar irradiation is determined to be $206 \mathrm{Wh} / \mathrm{m}^{2}$ which yields an annual requirement of $286 \mathrm{MWh} / \mathrm{m}^{2}$ necessitating a panel area of $1380 \mathrm{~m}^{2}$. A typical solar panel has an area of $1.64 \mathrm{~m}^{2}$ so the village would require 842 panels or 17 for each home. With the large number of rivers and waterways in Uttar Pradesh, together with the low lying nature of the terrain the type of waterway available would be a stream with a $0.5 \mathrm{~m}^{3} / \mathrm{s}$ flow rate. Assuming a $5 \mathrm{~m}$ head this would yield a power in the order of $21 \mathrm{~kW}$, most effectively met with a $30 \mathrm{~kW}$ propeller or Kaplan turbine.

\section{B. South Dakota}

A summary of local conditions yields:

(i) huge variation in temperature (from below freezing to over $30^{\circ} \mathrm{C}$ );

(ii) relatively dry, few rivers;

(iii) high elevation;

(iv) moderate to high average wind speeds;

(v) long days of relatively high solar irradiation.

Initial solutions could potentially be solar power and wind power, due to the high solar irradiation and wind speeds respectively. Hydropower appears to be unviable due to the relative aridness of the area.

Data gathered from Rapid City, the nearest solar data source, approximately $150 \mathrm{~km}$ from Pine Ridge, gives a daily average solar irradiation of $4.02 \mathrm{kWh} / \mathrm{m}^{2}$, which yields an annual irradiation of $1.47 \mathrm{MWh} / \mathrm{m}^{2}$ [12]. This therefore requires $703 \mathrm{~m}^{2}$ of solar panels which equates to 1041 of the selected panels, or 21 per home, in order to generate $100 \%$ of the energy requirements.
The size of wind turbine required to meet $100 \%$ of the power demands of the hypothetical settlement can be calculated from equation 3 . The average wind speed in the area is $5 \mathrm{~m} / \mathrm{s}$ so the total area swept by turbines needed to satisfy power demand of $171 \mathrm{~kW}$ would be $561 \mathrm{~m}^{2}$, which equates to a $5.95 \mathrm{~m}$ radius turbine for each of the 50 homes.

\section{Solukhumbu District - Nepal}

Summary of local conditions:

(i) high elevation and steep slopes;

(ii) year round low temperatures;

(iii) high precipitation;

(iv) moderately high wind speeds;

(v) relatively long days.

Hydropower appears to be a viable candidate, given the elevation and precipitation, as does wind power due to the moderately high wind speeds. Solar power may also be viable due to the relatively long days. Using data from the nearest data source, Kathmandu, the daily average solar irradiation is $5.18 \mathrm{kWh} / \mathrm{m} 2$ [11]. This can be extrapolated to an annual solar irradiation of $1.89 \mathrm{MWh} / \mathrm{m}^{2}$ requiring a solar panel area of $1320 \mathrm{~m}^{2}$ equating to 808 of the selected solar panels or 16 per home.

Wind power also appears to be viable. The average wind speed in the area is $5 \mathrm{~m} / \mathrm{s}$. This therefore requires (eqn 3 ) a total area of $5561 \mathrm{~m}^{2}$, which is also the equivalent of a $5.95 \mathrm{~m}$ radius turbine for each home.

Mountain streams are typically small, therefore it is assumed that the streams available in Solukhumbu equate to a small stream with a flow rate of $0.5 \mathrm{~m}^{3} / \mathrm{s}$, which will (eqn 1) require an $82 \mathrm{~m}$ head to generate the $171 \mathrm{~kW}$ power required.

\section{Tristan da Cunha - South Atlantic}

Summary of local conditions:

(i) heavy year round rainfall, single water source;

(ii) high elevation and steep slopes;

(iii) strong winds throughout the year;

(iv) volcanic activity;

(v) moderately long days;

(vi) mild temperatures.

The volcanic activity suggests that geothermal energy is potentially viable at this location. Strong winds and heavy rainfall suggests that both wind power and hydropower could also be viable whilst the long days means that solar power could potentially supplement this.

There is some data available for Tristan da Cunha. On the island there are four $200 \mathrm{kVA}$ substations and an additional $315 \mathrm{kVA}$ substation [13], which suggests that the total demand on the island does not exceed $1120 \mathrm{~kW}$. Thus, the value for the peak power demand for Tristan da Cunha used in this report will be $1115 \mathrm{~kW}$, yielding an annual energy consumption for the entire territory of St Helena, Ascension and Tristan da Cunha of 7.44 MWh, 
which yields an energy per capita of $957 \mathrm{kWh}$, the total population of the territory being 7780 [14], with the total energy consumption by the 267 residents of Tristan da Cunha being $255 \mathrm{MWh}$.

Using data gathered from NASA, the daily average solar irradiation is $4.02 \mathrm{kWh} / \mathrm{m}^{2}$ [15], which yields an annual irradiation of $1468 \mathrm{kWh} / \mathrm{m}^{2}$ which (eqn 2) will require $1703 \mathrm{~m}^{2}$ of solar panel area equating to 929 panels in total for the whole community.

The strong winds on Tristan da Cunha also make wind power viable. The average wind speed is $11.5 \mathrm{~m} / \mathrm{s}$, which (eqn 3) yields a wind turbine area of $2980 \mathrm{~m}^{2}$.

\section{Limitations of the Research}

There are a number of limitations to this work.

\section{A. Data}

There is a lack of reliable data available for the locations since by their very nature, remote villages are not widely visited and communication is limited. As such, specific data is hard to come by, leading to data from the nearest weather stations being used. Assumptions had to be made about the site, and factors such as local elevation, stream flow and shade all had to be estimated. There is also no reliable population and energy consumption data available, with the exception of Tristan a Cunha, hence the use of a typical energy use table (Table I). This lack of data also led to some potential technologies such as biofuels and geothermal power not being investigated. There were also limits in the data on the technologies to be used. Manufacturers' descriptions were the only available data which may be favourable to the manufacturer. The logistics, installation feasibility and installation costs were also not taken into account or any government incentives which may have offset some of the costs.

\section{B. Accuracy \& Applicability}

On site exploration could not be undertaken which would allow specific data for each settlement rather than general data about the area in which the settlement is situated. On site data would also enable variations in parameters to be taken into consideration. For example, it is assumed in this report that heavy rainfall at the location will increase the volume of water in local waterways and hence a higher flow rate. However, heavy rainfall (or drought) upstream towards the waterway's source could also impact the flow rate at the potential site. Local data would also engender a greater understanding of the geography of the site and whether the location is in fact suitable for large structures such as wind turbines. It would also allow the debris levels in any water sources to be observed [6], since high levels of debris can reduce the efficiency of water turbines and even cause their shutdown. Further research could also include a detailed look into the logistics of installing and maintaining the turbines and generators. Operation and maintenance from the local population also needs to be considered.

Other possible solutions have been disregarded in this work e.g. geothermal and biofuels solutions to meeting energy demands in a sustainable manner. A thorough site surveillance would determine the arable area available to grow crops for biofuels. The biofuel solution can be established in an irresponsible manner and so has not been considered here. In Tristan da Cunha, geothermal energy is likely to be a viable solution due to local tectonic activity but again a thorough surveillance is necessary.

Finally, direct heat energy, rather than electricity could be considered for cooking and heating. Technologies that could provide direct heat include geothermal, heat pumps, thermodynamic solar panels and biofuels. All of these could supply direct heat energy instead of requiring electricity to be produced which is then converted to heat energy which would reduce the electricity demand.

All of these factors could lead to a re-evaluation of the cost and feasibility of the projects.

\section{Conclusion}

This work determines that wind, hydro and solar power can all be useful solutions in off-grid, small scale renewable energy generation in remote locations. It also finds that there is an identifiable need for such solutions in many locations around the globe, in order to modernize and reduce poverty in isolated communities. However, it also finds that each method of generation has different operating conditions that limit their use to certain climates and regions. As such, it is important that research on sites and locations is undertaken before recommending any particular method of renewable energy generation.

\section{References}

[1] C-J.Dalgaard, H.Strulik, "Energy Distribution and Economic Growth, Resource \& Energy Economics", Vol 33, Issue 4, pp. 782-797, Nov 2011.

[2] J.Urpelainen, "Off grid Solar Power for rural India", retrieved from: http://www.theenergycollective.com.

[3] J.Terraphon-Pfaff, J.Dienst, C.Konig \& W.Ortiz, "How effective are small scale energy interventions in developing countries", Applied Energy, Vol 135, pp. 809814, Dec 2014. 
[4] Macro Trends, "Crude Oil Price History chart", retrieved from http://www.macrotrends.net.

[5] US Dept of Energy - Energy Efficiency \& Renewable Energy: Tribal Energy program, retrieved from http://apps1.eere.energy.gov.

[6] R.Budiarto, M.K.Ridwan, A.Haryoko, Y.S.Anwar, K.Suhono \& Suryopratomo, "Sustainability challenge for small scale renewable energy use in Yogyakarta", Procedia Environmental Sciences, Vol 17, pp. 513-518, 2013.

[7] W.Bauer, S.Bauer \& T.Bauer, "Energy and Greenhouse Gas analysis for biogas powerplants", ICREPQ'12, Santiago.

[8] B.S.Purwono, Suyanta \& Rahbini, "Biogas digester as an alternative energy strategy in the marginal villages in Indonesia", Energy Procedia, Vol 132, pp. 136-144, 2013.

[9] Energy Bible, "Wind Speed and Wind Energy", retrieved from http://www.energybible.com.

[10] Vasuda Foundation, "Current Status of Village Electrification in Uttar Pradesh", retrieved from http://www.vasuda-foundation.org, 2013.

[11] NREL, "India Solar resource Data: Hourly", retrieved from http://rredc.nrel.gov.

[12] US Climate Data, "Map of Pine Ridge, South Dakota", retrieved from http://www.usclimatedata.com.

[13] TrisandaCunha.org, "Welcome to Trisan Da Cunha", retrieved from http://www.tristandc.com.

[14] CIA, "Africa: St Helena, Ascension and Tristan da Cunha", retrieved from http://www.cia.gov.

[15] NASA Atmospheric Science data Center, "NASA Surface metrology and Solar Energy", retrieved from https://eosweb.larc.nasa.gov. 